\title{
Comparison of aqueous seasoning cube solution and nutrient broth as culture media for production of the biocontrol agent Bacillus megaterium in the laboratory, and for suppression of rice grain discolouration in the field
}

\author{
Mana Kanjanamaneesathian* and Pimjai Meetum \\ Faculty of Animal Science and Agricultural Technology, Silpakorn University, Phetchaburi IT \\ campus, Cha-Am, Phetchaburi, 76120, Thailand \\ ${ }^{*}$ Corresponding author: Kanjanamaneesat_m@su.ac.th
}

\begin{abstract}
Bacillus megaterium is a beneficial bacterium that is used as a biological control agent (BCA) against the fungi Rhizoctonia solani, Fusarium sacchari and Curvularia lunata, which attack rice plants. However, the cost of preparing the bacterium using standard nutrient broth is prohibitively expensive on a large scale. Therefore, a low-cost product (seasoning cube, a common ingredient for cooking) was examined as an alternative nutrient medium. Bacillus megaterium was cultured in either nutrient broth or in dissolved seasoning cube. These cultures were evaluated for their effect on the growth of rice seedlings in the laboratory and to suppress grain discolouration of rice in small-scale field trials. Bacillus megaterium cultured with a seasoning cube was as effective as standard nutrient broth for the growth of rice seedlings in the laboratory. It also suppressed grain discolouration disease of rice in small-scale field trials. Use of a seasoning cube is suitable for culturing $B$. megaterium and should be recommended to farmers.
\end{abstract}

Keywords microbial inoculant, simple culture of bacterial antagonist

\section{INTRODUCTION}

Production of rice (Oryza sativa) currently depends heavily on the application of chemical fertilisers for plant growth (Arif et al. 2018) and pesticides for pest control (Rahaman et al. 2018). However, the injudicious use of these chemicals has raised public concern about farmers' health and also pollution in the rice ecosystem (Pingali \& Roger 1995). These issues have driven increased consumer demand for safe produce (Cronin 2015). This demand has paved the way for research and development to replace control measures based on the application of synthetic pesticides with safer biological products (Schisler \& Slininger 1997).

Beneficial bacteria have been used for sustainable agriculture (Gholamalizadeh et al.
2017). Inoculation of plants with plant growthpromoting rhizobacteria (PGPR) to enhance crop yields and plant performance is a proven technology (Bashan et al. 2014; Gholamalizadeh et al. 2017). Two main aspects dominating the success of the application of PGPR are: (a) the effectiveness of the bacterial isolates; and (b) the use of suitable application technology (Bashan et al 2014).

In Thailand, Bacillus megaterium, originally isolated from rice paddy soil, is a beneficial PGPR that is effective in the control of rice diseases caused by fungi (Kanjanamaneesathian et al. 2009). For example, Bacillus megaterium is antagonistic to Rhizoctonia solani (a causal agent of rice sheath blight disease) (Kanjanamaneesathian et al. 1998) and to both Fusarium sacchari and Curvularia 
lunata (two main causal agents of rice grain discoloration disease) (Kanjanamaneesathian et al. 2009). Bacillus megaterium has been formulated into various forms such as floating pellets, (Wiwattanapatapee et al. 2004), effervescent granules (Wiwattanapatapee et al. 2007), water-soluble granules (Chumthong et al. 2008), alginate microcapsules (Wiwattanapatapee et al. 2013) and spraydried powders (Chumthong et al. 2016). These formulations have been tested for their efficacy in greenhouse trials and in pilot-scale field trials using small plots during the process of product development (Wiwattanapatapee et al. 2004; Wiwattanapatapee et al. 2007; Wiwattanapatapee et al. 2013; Chumthong et al. 2016). A preparation containing fresh cell suspension of $B$. megaterium (Kanjanamaneesathian \& Meetum 2017) and also water-soluble granules of this bacterium have both been adopted for use to control rice diseases by the rice farmers in Uttaradit province, Thailand (Chumthong et al. 2008; Kanjanamaneesathian et al. 2009; Kanjanamaneesathian 2015).

The continual use of a preparation of the fresh cell suspension of $B$. megaterium (Kanjanamaneesathian \& Meetum 2017) and water-soluble granules by the rice farmers to control fungal diseases in rice (Kanjanamaneesathian et al. 2009) is an indicator that rice farmers are satisfied with the efficacy of this bacterium in controlling fungal diseases of rice. Whilst growers are satisfied with efficacy, further research to improve the technique of culturing B. megaterium is required. There are two major issues which should be promptly addressed. First, nutrient broth (NB) as a source of nutrient is expensive and is mainly suitable for use in the laboratory for research. Second, preparation of water-soluble granules (Chumthong et al. 2008) or fresh cell suspension in the laboratory as an inoculum starter are labour intensive and, therefore, expensive, which hinders their use by rice farmers (Kanjanamaneesathian \& Meetum 2017).

Seasoning cubes are commonly used in cooking. The ease to access to seasoning cubes and the lower cost of this product compared to nutrient broth (NB) makes seasoning cubes an appealing choice to use for culturing $B$. megaterium. The main aim of this research is to evaluate the efficacy of $B$. megaterium cultured in water containing dissolved seasoning cubes in promoting seedling growth of rice in the laboratory and suppressing grain discolouration disease of rice in the field. In addition, the effect of bacterial-culture aeration method was evaluated.

\section{MATERIALS AND METHODS}

Comparison of nutrient sources to prepare a simple culture of $B$. megaterium

A simple culture of B. megaterium was prepared as described by Kanjanamaneesathian and Meetum (2017) using NB for 24 hours. One millilitre aliquots $\left(3.3 \times 10^{7} \mathrm{CFU} / \mathrm{mL}\right)$ were then cultured in translucent (6 litre) plastic drinking-water tanks using either nutrient broth (NB), water containing a dissolved seasoning cube or water as the nil control and each treatment had two replications. Either five grams of NB [commercial dehydrated NB $\left(\right.$ Difco $\left.^{\mathrm{TM}}\right)$ containing beef extract and peptone] or half of a 10-g common household seasoning cube (Knorr brand, Unilever, Thailand) was added to the water tank containing 5 litres of clean commercially available drinking water [clear, tasteless water, filtered by reverse osmosis (RO), and sterilised with ultra-violet and ozone treatment with $\mathrm{pH}=6.6$ ]. The seasoning cube is composed by weight of $40 \%$ iodised salt, $31.9 \%$ monosodium glutamate, $13 \%$ palm oil, $8 \%$ sugar, $3.8 \%$ dehydrated pork meat, $1.5 \%$ soy sauce, $1.4 \%$ spice and $0.4 \%$ concentrated pork broth. This bacterium was also inoculated to the water tank without the addition of either NB or common household seasoning cube for use as nil control treatment. Each culture was aerated using an aquarium air pump and the air tube entered the tank through a cotton-wool plug to prevent contamination. A sterile aquarium air stone attached at the end of the tube was immersed in the water tank to aerate the bacterial culture. The cultures were incubated at room temperature $\left(25-32^{\circ} \mathrm{C}\right)$ for four days before further use. 


\section{Determination of bacterial growth}

The number of bacteria in each of the cultures described above was assessed 24, 48, 72 and 96 hours after inoculation using a spreadplate technique on nutrient agar [commercial dehydrated NA (Difco ${ }^{\text {ix }}$ ) containing beef extract, peptone and agar].

The growing colonies of $B$. megaterium were counted in triplicate (per water tank) after incubation at room temperature $\left(37^{\circ} \mathrm{C}\right)$ for 24 hours and the values were averaged and recorded as colony forming units $(\mathrm{CFU} / \mathrm{mL})$ at $24,48,72$ and 96 hours after inoculation.

\section{Comparison of bacterial-culture aeration method}

Sterile aquarium air stones and sterile straws (used for drinking) were evaluated as materials to aerate the bacterial culture (Kanjanamaneesathian \& Meetum 2017). There were four treatments involving $B$. megaterium cultured in either seasoning cube or nutrient broth (NB) aerated with either a sterile aquarium air stone or a sterile straw. There were two replicates of each treatment. The bacterium was cultured and bacterial growth was determined in same conditions as described above.

\section{Efficacy of $B$. megaterium culture to promote seedling growth of rice}

Bacillus megaterium cultured with water containing a seasoning cube as the source of nutrient, and a sterile straw as the material to aerate the culture, was used to soak seeds of three rice varieties (RD31, Khao Dawk Mali105 and Kiew Ngu glutinous rice) to assess its efficacy in promoting seedling growth.

Each variety of rice seeds was soaked in sterile water for 24 hours then the water was decanted. The pre-soaked rice seeds were then soaked for a further 24 hours in $100 \mathrm{~mL}$ of a three-day-old culture of the BCA $\left(7.6 \times 10^{6} \mathrm{CFU} / \mathrm{mL}\right)$ prior to 10 -fold dilution in water. The solution was decanted off and the damp seeds were sown onto sterile sand in the trays in the laboratory. There were four replicates for each treatment (with 100 seeds per replication). Seeds of each rice variety soaked in sterile water were used as a nil control.

Growth of rice seedlings was determined after 20 days at room temperature $\left(25-32^{\circ} \mathrm{C}\right)$. Whole seedlings were carefully uprooted and thoroughly washed with running water. Shoots and roots were separated and the samples of both parts were then air dried in a hot oven at $70^{\circ} \mathrm{C}$ for 3 days before weighing.

\section{Large-scale application of bacterial cultures to rice}

Bacillus megaterium culture prepared aseptically in aqueous seasoning cube solution was used by a rice farmer in each of two locations at Uttaradit province, Thailand between August-December 2018. One rice farmer (at Thong Sean Kan, Uttaradit province) used the bacterial culture to grow Kiew Ngu glutinous rice, whilst the other rice farmer (at Pichai, Uttaradit province) used the bacterial culture to cultivate Khao Dawk Mali 105. The farmers applied the bacterial culture four times; once to the germinating rice seeds and thrice to the growing rice plants in the field.

For the seed treatment, each farmer used the bacterial cultures prepared as described above to drench germinating rice seeds. Sixty kilograms of rice seeds at each field were soaked in water in a clay jar for 24 hours. Germinating rice seeds with emerging radicles were then taken out of the water and put onto a plastic sheet. Five litres of the 96-hour-old bacterial culture was diluted with 50 litres of tap water and the mixture was sprinkled onto the rice seeds and these bacterialsoaked rice seeds were covered with a ramie (Boehmeria nivea) bag for 24 hours before they were broadcast onto the rice field at each location.

For spraying, ten litres of the 96-hour-old bacterial culture was diluted with 100 litres of tap water and the mixture was sprayed onto one rice plot, over 0.48 ha (3.0 rai; a Thai area unit). This rice plot ( $0.48 \mathrm{ha}$ ) was partitioned into four spatially separated subplots which were used as replicates. The bacterial culture was sprayed three times, each at tillering stage, booting stage and milk stage (IRRI 2002). At each location, another rice plot of the same size (located opposite the treatment plot and separated by a walkway 
2-metre wide) did not receive any bacterial spray. This plot was used as the nil control.

\section{Collection of rice samples with grain discolouration (GD) symptoms for disease assessment}

The severity of GD of each rice variety was assessed two weeks after harvesting the rice panicles based on the standard evaluation system for rice (SES) (IRRI 2002). One hundred rice panicles, which had been sprayed with the bacterial culture, were randomly harvested from the area of four $\mathrm{m}^{2}$ (dimension $2 \times 2 \mathrm{~m}$ ) located at the centre of each subplot from each location. Another 100 rice panicles, which had not been sprayed with the bacterium, were harvested from each subplot from each location and used as the nil control. These rice panicles were put in the paper bags and subsequently transported to the laboratory for disease assessment. The scale of GD severity was classified based on the grains with severely discoloured glumes in the panicle. According to this scale, 0 represented no incidence, 1 represented less than 1\% incidence, 3 represented $1-5 \%$ incidence, 5 represented $6-25 \%$ incidence, 7 represented $26-50 \%$ incidence, and 9 represented 51-100\% incidence, based on SES (IRRI 2002).

\section{Statistical analysis}

Data collected were subjected to statistical analysis using the $\mathrm{R}$ program (R-language and environment for statistical computing and graphics). One-way analysis of variance was carried out on number of viable $B$. megaterium cells, weight of shoot and root in the laboratory and the severity of GD in the field without data transformation. The mean values $( \pm \mathrm{SE})$ were compared with Duncan's Multiple Range Test at $\mathrm{P}<0.05$.

\section{RESULTS}

Source of nutrient to prepare a simple culture of $B$. megaterium

The number of viable Bacillus megaterium cells in NB (Difco ${ }^{\mathrm{TM}}$ ) was higher than that in seasoning cube (Knorr brand, Unilever, Thailand), although there was no statistically significant difference in the number of viable $B$. megaterium cells in both cultures from 24 hours to 96 hours. However, both cultures contained significantly more viable B. megaterium cells than water $(\mathrm{P}<0.05$; Table 1$)$.

\section{Comparison of bacterial-culture aeration method}

Overall, there was no difference in the use of a sterile aquarium air stone or a sterile drinking straw simple culture of $B$. megaterium with either nutrient broth (NB) and seasoning cube (SC) for 96 hours (Table 2).

The efficacy of $B$. megaterium culture to promote seedling growth of rice

Bacillus megaterium cultured in either NB or aqueous seasoning cube (SC) solution promoted shoot (but not root) growth of $\mathrm{RD} 31$ rice seedlings compared with the water-only control although NB was more effective than SC (Table 3).

Table 1 Mean $( \pm \mathrm{SE})$ number of viable cells of $B$. megaterium $\left(\mathrm{x} 10^{6} \mathrm{CFU} / \mathrm{mL}\right)$ in nutrient broth $(\mathrm{NB})$, common household seasoning cube and water after 24, 48, 72 and 96 hours of culturing. Means in each column followed by the same letter are not significantly different by Duncan's Multiple Range Test at $\mathrm{P}<0.05$.

\begin{tabular}{lcrrr}
\hline Medium & \multicolumn{4}{c}{ Duration of culturing Bacillus megaterium (hours) } \\
\cline { 2 - 5 } & \multicolumn{1}{c}{48} & \multicolumn{1}{c}{72} & \multicolumn{1}{c}{96} \\
\hline Nutrient broth & $32.6 \pm 4.5 \mathrm{a}$ & $12.3 \pm 1.2 \mathrm{a}$ & $17.0 \pm 1.6 \mathrm{a}$ & $15.8 \pm 2.0 \mathrm{a}$ \\
Seasoning cube & $24.5 \pm 3.9 \mathrm{a}$ & $9.5 \pm 0.1 \mathrm{a}$ & $12.1 \pm 1.6 \mathrm{a}$ & $11.4 \pm 0.8 \mathrm{a}$ \\
Water & $4.05 \pm 0.6 \mathrm{~b}$ & $4.6 \pm 0.2 \mathrm{~b}$ & $1.1 \pm 0.1 \mathrm{~b}$ & $5.5 \pm 0.6 \mathrm{~b}$ \\
\hline
\end{tabular}


Table 2 Mean $( \pm \mathrm{SE})$ number of viable cells of $B$. megaterium $\left(\mathrm{x} 10^{6} \mathrm{CFU} / \mathrm{mL}\right)$ in nutrient broth $(\mathrm{NB})$ and seasoning cube (SC) when the culture is aerated with either aquarium air stone or straw (used for drinking). Means in each column followed by the same letter are not significantly different by Duncan's Multiple Range Test at $\mathrm{P}<0.05$.

\begin{tabular}{lcccc}
\hline Condition & \multicolumn{4}{c}{ Duration of culturing Bacillus megaterium (hours) } \\
\cline { 2 - 5 } & 24 & 48 & 72 & 96 \\
\hline NB and air stone & $19.2 \pm 4.2 \mathrm{a}$ & $57.0 \pm 4.0 \mathrm{a}$ & $11.2 \pm 1.9 \mathrm{a}$ & $9.0 \pm 1.0 \mathrm{ab}$ \\
NB and straw & $12.3 \pm 1.9 \mathrm{ab}$ & $18.5 \pm 0.5 \mathrm{~b}$ & $16.5 \pm 5.5 \mathrm{a}$ & $14.0 \pm 4.0 \mathrm{a}$ \\
SC and air stone & $15.3 \pm 1.8 \mathrm{ab}$ & $7.5 \pm 4.6 \mathrm{bc}$ & $8.7 \pm 0.4 \mathrm{a}$ & $6.9 \pm 0.4 \mathrm{ab}$ \\
SC and straw & $6.8 \pm 0.4 \mathrm{~b}$ & $5.3 \pm 1.4 \mathrm{c}$ & $7.6 \pm 0.1 \mathrm{a}$ & $3.7 \pm 0.7 \mathrm{~b}$ \\
\hline
\end{tabular}

Table 3 Mean $( \pm S E)$ of dried weight of shoot and root of RD31, Khao Dawk Mali (KDM) 105 and Kiew Ngu (KN) glutinous rice. Means in each column followed by the same letter are not significantly different by Duncan's Multiple Range Test at $\mathrm{P}<0.05$.

\begin{tabular}{lll}
\hline Treatment & Shoot $(\mathrm{g})$ & Root $(\mathrm{g})$ \\
\hline RD31 in NB & $0.7 \pm 0.0 \mathrm{a}$ & $0.7 \pm 0.1 \mathrm{a}$ \\
RD31 in SC & $0.6 \pm 0.0 \mathrm{~b}$ & $0.6 \pm 0.1 \mathrm{a}$ \\
RD31 in water & $0.5 \pm 0.0 \mathrm{c}$ & $0.5 \pm 0.1 \mathrm{a}$ \\
KDM 105 in NB & $1.0 \pm 0.1 \mathrm{a}$ & $1.0 \pm 0.1 \mathrm{a}$ \\
KDM 105 in SC & $0.8 \pm 0.1 \mathrm{a}$ & $1.0 \pm 0.1 \mathrm{a}$ \\
KDM105 in water & $0.3 \pm 0.1 \mathrm{~b}$ & $0.7 \pm 0.0 \mathrm{~b}$ \\
KN in NB & $1.0 \pm 0.1 \mathrm{a}$ & $1.6 \pm 0.1 \mathrm{a}$ \\
KN in SC & $1.0 \pm 0.2 \mathrm{a}$ & $1.5 \pm 0.1 \mathrm{a}$ \\
$\mathrm{KN}$ in water & $0.6 \pm 0.0 \mathrm{a}$ & $1.1 \pm 0.1 \mathrm{~b}$ \\
\hline
\end{tabular}

The bacterium in either NB or aqueous seasoning cube solution also increased growth of both shoot and root of Khao Dawk Mali 105 seedlings (Table 3). The cell suspension of $B$. megaterium in $\mathrm{NB}$ and aqueous seasoning cube solution enhanced root (but not shoot) growth of Kiew Ngu (glutinous rice) rice seedlings (Table 3 ).

The efficacy of $B$. megaterium culture to suppress GD of rice

The bacterial culture of $B$. megaterium in seasoning cube effectively reduced the severity of GD of rice in both Khao Dawk Mali 105 and Kiew Ngu (glutinous rice) in the field (Table 4).

\section{DISCUSSION}

According to Bashan et al. (2014), there are three essential characteristics for microbial inoculants to have beneficial effects on crops: (i) the inoculant should support the growth of the intended microorganisms; (ii) it should support the necessary number of viable microbial cells in good physiological condition for an acceptable period of time; and (iii) it should also deliver enough microorganisms at the time of inoculation to reach a threshold number of bacteria that is usually required to obtain a plant response.

Seasoning cube, a cheap ingredient for cooking, supported growth of B. megaterium, 
Table 4 Mean $( \pm$ SE) of the scale of grain discoloration (GD) severity (scale 0-9) of rice var. Kiew Ngu $(\mathrm{KN})$ glutinous rice and Khao Dawk Mali (KDM) 105. Means in each column followed by the same letter are not significantly different by Duncan's Multiple Range Test at $\mathrm{P}<0.05$.

\begin{tabular}{lcc}
\hline Treatment & \multicolumn{2}{c}{ Rice variety } \\
\cline { 2 - 3 } & $\mathrm{KN}$ & KDM 105 \\
\hline Bacterial spray & $3.6 \pm 0.1 \mathrm{~b}$ & $3.9 \pm 0.2 \mathrm{~b}$ \\
Nil control (no spray) & $7.1 \pm 0.1 \mathrm{a}$ & $6.3 \pm 0.2 \mathrm{a}$ \\
\hline
\end{tabular}

used in our study, well enough to replace NB, an expensive ingredient for laboratory use, for culturing this bacterium (Tables $1 \& 2$ ). Cultures of $B$. megaterium prepared using a seasoning cube also promoted seedling growth of RD31 (shoot), Khao Dawk Mali 105 (shoot and root) and Kiew Ngu glutinous rice (root) (Table 3). This bacterial culture was also suppressed GD of rice in both Khao Dawk Mali 105 and Kiew Ngu glutinous rice in small-scale field trials (Table 4). Nevertheless, the rice plants that are sprayed with the nutrient solution (without the bacterium) should be included in the next experiment to determine the effect of nutrient and moisture on the severity of GD because there may have been some components in this solution that might affect the disease severity. These current results, however, indicated that a culture medium using a seasoning cube was efficient for production of a $B$. megaterium cell suspension and that the resulting cell suspension not only elicited a positive growth response from rice (Table 3) but also protected rice plants from infection by the causal agents of GD (Table 4). To substitute chemical fungicides with microorganisms for use in agriculture, the first step is to identify the best strain of bacteria or a microbial consortium for the intended effect on the target crop (Bashan et al. 2014). Bacillus vietnamensis was reported to produce high quantity of indole3 -acetic acid (IAA) and could be considered as a bacterial inoculant to use as an alternative to chemical fertilisers (Gholamalizadeh et al. 2017). Bacillus megaterium, used in our study, also has potential to use in promoting rice productivity in Thailand. However, its mechanisms contributing to the promotion of rice growth should be further investigated.
The efficacy of $B$. megaterium in promoting growth in rice (Table 3 ) has validated previous field observations of increased rice growth in Uttaradit province, Thailand (unpublished data). Rice farmers in Uttaradit province have used the liquid cell suspension of $B$. megaterium to soak one-day-old germinating rice seeds for 24 hours before they are broadcast onto the paddy field. This practice allows the introduced $B$. megaterium to colonise the emerging active radicle, which forms the basis of the root system and facilitate the successful colonisation of roots by the introduced bacterium. According to Roy et al. (2015), the bacteria must come into contact with the roots for successful colonisation. Without good and secure attachment, the beneficial rhizobacteria are not capable of promoting plant growth.

Fresh cell preparations of bacterial inoculants have limitations for use in rice fields (Roy et al. 2015) because of a rapid decline of introduced bacteria. However, the fresh cell preparation of the bacterium can be effective if it is adequately applied to the environmental niche based on the understanding of the factors contributing to disease development. Severity of GD of rice was significantly reduced when a rice field was sprayed three times (at rice growth stages: tillering, booting, and milk) with a simple culture of $B$. megaterium (Kanjanamaneesathian \& Meetum 2017). Bacillus megaterium has been found to be highly antagonistic to Fusarium sacchari and Curvularia lunata, two major fungal causal agents of GD in the laboratory tests (unpublished data). These plant pathogenic fungi produce airborne spores which are prevalent in the rice fields (Almaguer et al. 2012). The frequent applications of the fresh cell preparation of $B$. megaterium 
should reduce the primary inoculum of these fungi, contributing to the reduced GD severity.

The replacement of NB with a seasoning cube, as the nutrient source, in the simple culture of $B$. megaterium will facilitate the promotion of using bacterial inoculants by the local agricultural officials and the rice farmers. The development of a paper-based inoculum of $B$. megaterium (Kanjanamaneesathian \& Nimanong 2019) will also promote the reception of this technique even further because of the ease of its use as a starter to produce the bacterial culture. As farmers are expected to produce the bacterial culture when it is needed for applying to the rice fields, simplicity is very important with respect to access to both the equipment and the bacterial inoculum that are required to use for producing the bacterial culture.

\section{CONCLUSIONS}

A seasoning cube is a suitable nutrient source for culturing $B$. megaterium. Results from small laboratory and field trials indicate that a simple culture of the bacterium in a seasoning cube solution can be effective in promoting growth of rice seedlings and suppressing GD of rice. Therefore, a simple culture of the BCA using a seasoning cube should be recommended to the farmers for use in growing rice.

\section{ACKNOWLEDGEMENTS}

The authors would like to thank the Faculty of Animal Science and Agricultural Technology (ASAT), Silpakorn University, Phetchaburi IT campus, Cha-Am, Phetchaburi, for providing laboratory facilities. ASAT is also appreciated to support the first author to present this research at the New Zealand Plant Protection Society conference 2019. The heads of the local agricultural extension at Pichai office and Thong Sean Kan office, Department of Agricultural Extension, Uttaradit province, Ministry of Agriculture and Agricultural Cooperatives, Thailand are appreciated for facilitating access to two rice farmers for field trials.

\section{REFERENCES}

Almaguer M, Rojas TI, Rodríguez-Rajo FJ, Aira MJ 2012. Airborne fungal succession in a rice field of Cuba. European Journal of Plant Pathology 133: 473-482.

Arif M, Zahid M, Tasneem M, Bashir F, Shafiq M, Akhtar N, Yaseen G, Anwar A, Tariq I 2018. Exogenously applied nitrogen and zinc fertilizers improved the rice productivity. Current Investigations in Agriculture and Current Research 4: 503-507.

Bashan Y, de-Bashan LE, Prabhu SR, Hernandez JP 2014. Advances in plant growth-promoting bacterial inoculant technology: formulations and practical perspectives (1998-2013). Plant and Soil 378: 1-33.

Chumthong A, Kanjanamaneesathian M, Pengnoo A, Wiwattanapatapee R 2008. Water-soluble granules containing Bacillus megaterium for biological control of rice sheath blight: Formulation, bacterial viability and efficacy testing. World Journal of Microbiology and Biotechnology 24: 24992507.

Chumthong A, Wiwattanapatapee R, Viernstein $\mathrm{H}$, Pengnoo A, Kanjanamaneesathian M 2016. Spray-dried powder of Bacillus megaterium for control of rice sheath blight disease: formulation protocol and efficacy testing in laboratory and greenhouse. Cereal Research Communications 44: 131-140.

Cronin C 2015. The organic food industry: an analysis of supply and demand via aggregate prices. Summer Program for Undergraduate Research (SPUR), University of Pennsylvania, USA. 14 p.

Gholamalizadeh R, Khodakaramian G, Ebadi AA 2017. Assessment of rice associated bacterial ability to enhance rice seed germination and rice growth promotion. Brazilian Archives of Biology and Technology 60: 1-13.

IRRI 2002. Standard Evaluation System for Rice (SES). International Rice Research Institute. Los Baños. The Republic of the Philippines.

Kanjanamaneesathian M, Kusonwiriyawong C, Pengnoo A, Nilratana L 1998. Screening of potential bacterial antagonists for control 
of sheath blight in rice and development of suitable bacterial formulations for effective application. Australasian Plant Pathology 27: 198-206.

Kanjanamaneesathian M, Chumthong, A, Pengnoo A, Wiwattanapatapee R 2009. Bacillus megaterium suppresses major Thailand rice diseases. Asian Journal of Food and Agro-Industry (Special Issue): 154-159.

Kanjanamaneesathian M 2015. Bacillus for Rice Cultivation in Thailand. In: Liong Min-Tze Ed. Beneficial Microorganisms in Agriculture, Aquaculture and Other Areas. Springer International Publishing, Switzerland. Pp. 81-100.

Kanjanamaneesathian M, Meetum P 2017. Efficacy of a simple liquid culture of Bacillus megaterium in suppressing grain discoloration disease of rice (Oryza sativa). New Zealand Plant Protection 70: 196-202.

Kanjanamaneesathian M, Nimanong W 2019. Paper-based inoculum of Bacillus megaterium and its usage to produce a simple culture of the bacterium for application. New Zealand Plant Protection 72: 195-204.

Pingali PL, Roger PA 1995. Impact of pesticides on farmer health and the rice environment. International Rice Research Institute, Los Baños, The Republic of Philippines. 664 p.

Rahaman MM, Islam KS, Jahan M 2018. Rice farmers' knowledge of the risks of pesticide use in Bangladesh. Journal of Health \& Pollution 8: 1-9.

Roy M, Saha S, Das J, Srivastava RC 2015. Technologies of microbial inoculation in rice - A Review. Agricultural Reviews 36: 125-132.

Schisler DA, Slininger PJ 1997. Microbial selection strategies that enhance the likelihood of developing commercial biological control products. Journal of Industrial Microbiology and Biotechnology19: 172-179.

Wiwattanapatapee R, Pengnoo A, Kanjanamaneesathian M, Matchavanich W, Nilratana L, Jantharangsri A 2004. Floating pellets containing bacterial antagonistfor control sheath blight of rice: formulation, viability and bacterial release studies. Journal of Controlled Release 95: 453-460.

Wiwattanapatapee R, Chumthong A, Pengnoo A, Kanjanamaneesathian M 2007. Effervescent fast-disintegrating bacterial formulation for biological control of rice sheath blight. Journal of Controlled Release 119: 229-235.

Wiwattanapatapee R, Chumthong A, Pengnoo A, Kanjanamaneesathian M 2013. Preparation and evaluation of Bacillus megateriumalginate microcapsules for control of rice sheath blight disease. World Journal of Microbiology and Biotechnology 29: 14871497. 